\title{
新しいドライブ制御技術の考察*
}

安川シーメンスオートメーション・ドライブ株式会社 システム技術グループ 河 村 美智雄

\section{Consideration of the Latest Technology for Drive Control}

\section{Michio Kawamura}

Yaskawa Siemens Automation \& Drives Corp.

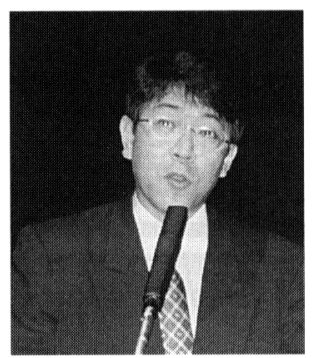

Recently, the application area of the variable speed drives for the paper making plants are expanding and methods of application are changing due to the rapid progress of inverter and servo technology.

On the other hand, the requirements toward the environment, such as correspondence to the low noise, the decrease of the electromagnetic noise, repression of the harmonic electrical current, become severe.

As consideration of the latest technology for drive controls of Yaskawa Siemens Automation \& Drives Corp., technology of synchronous drive with MASTERDRIVES MC, technology of 3-level PWM control for environment harmonic control with VARISPEED G 7 are mainly described in this papers. HOLLOW SHAFT AC SERVO DRIVES and inverter mounted SIMODRIVE POSMO A DRIVES are briefly explained as advanced drive technology.

分類： $V_{2}$ 紙パルプ工程制御システム, $\mathrm{U}_{7}$ 電気

\section{1.はじめに}

近年，製紙設備に扔けるドライブは，インバータ技 術やサーボ技術の急速な進展により，その適用範囲が 搪大し，また適用方法も変化しつつある。

汎用インバータによるファンやポンプ等の省エネル ギードライブからベクトル制御インバータによる抄紙 機，オフマシンコータ，ワインダ等の高精度，高性能 ドライブ，サーボドライブを用いた高速高応答ポジシ ヨニング用途まで, 可変速ドライブが幅広く適用され るようになってきた。可変速ドライブは，設備・機械 の機能, 性能の向上, コストダウン, 省エネルギーに 貢献してきたが, これらの要求に終着点はない。
一方, 環境に対する要求が厳しくなり, 低騒音への 対応, 電磁ノイズの低減, 商用電源に対する高調波の 抑制などの要求が強くなってきた。

本稿では新しいドライブ技術として, 近年印刷機械 業界で実用化が進んでいるドライブ間同期位相制御機 能を搭載した高性能システムインバータ MASTERDRIVES MCによるシャフトレスドライブとその応用 について述べる。次に世界で初沉用インバー夕に 3 レベル PWM 制御を搭載し, $400 \mathrm{~V}$ 級インバータの 潜在問題，特に対環境性能を著しく改善したVARISPEED G 7 インバータドライブについて紹介する。ま た，当社の特長あるドライブ製品である中空ドライブ 並びにインバータモー夕搭載ドライブについてその技 術を紹介する。

*平成 13 年度年次大会講演（講演 No. A 6) 


\section{2. ドライブ間同期位相制御技術と応用}

ここ数年，印刷機械業界においては，印刷ユニット 間をギヤ連結した従来のラインシャフト駆動方式から 各印刷ユニットを個別に駆動するシャフトレスドライ ブ方式への移行が進んでいる。シャフトレスドライブ 方式は長所が多く理想的な駆動方式であるが, 高精度 なドライブ間同期位相制御性能が求められる。また, この同期位相制御機能の応用として, ドライブ間の位 相差角比率を調整することによって超高精度比率（ド ロー）運転を実現し，ウェブの張力を精密にコントロ ールすることができる。

以下に, MASTERDRIVES MCを使用したドライ ブ間同期位相制御によるシャフトレスドライブについ て，その長所と応用例，制御技術について紹介する。 併せて MASTERDRIVES MCの特長を活かした適用 について述べる。

\subsection{MASTER DRIVES MC による \\ ドライブシステムの長所}

MASTERDRIVES MC は, $1: 10,000$ の広域速度制 御を可能としたドライブ装置で，そのドライブ間同期 位相制御により，従来の機械機構付き駆動部のシャフ トレスドライブ化が実現できるようになった。

速度制御範囲 $1: 10,000$ を実現するドライブでは低 速マシンや大径ロールのギヤレスダイレクトドライブ の実現が可能であり，また高速から超低速まで広範囲 の操業運転が要求される用途ではギヤ切り替え装置等 の余分な設備を省略することができる。これらの長所 は以下の通りである。

(1) 経済的である

・駆動系に介在するシャフト, ギヤ, クラッチ等が 不要となり, 機械各部が簡略化されるためイニシ
ヤルコストと保守のためのランニングコストが低 減できる。

・機械部分でのエネルギー損失が無くなり設備の省 エネルギー化が図れる。

(2) 駆動性能が向上する。

・ラインシャフトの枚じれ，ギヤ等のガ夕が低減さ

れ，機械系を含めた駆動精度が向上する。

(3) 保守性が向上する。

・機械部品の減少によりメンテナンス性が向上する。 ・整備，清掃作業が容易である。

（4）設備の計画が容易である。

・機械部の設計・手配が不要となり, 設備の計画が 容易となる。

（5）操作性が向上する。

・個別駆動によって単独で操作でき，原点合わせ等 の操作性が向上する。

\section{2 応用 例}

ここでは，ドライブ間同期位相制御と広範囲速度制 御の製紙機械設備における応用について一例を紹介す る。

1）同期位相制御の応用例

・ドライヤセクションのギヤレスドライブ（各シリ ンダドライブ，キャンバスドライブの同期運転) 薄物, 湿紙搬送用ペーパロール群のプーリ・ベル トレス，シャフトレス同期運転同期運転制御応用 の精密ドロー制御

2）広範囲速度制御の応用例

・多目的コータのダイレクトドライブ

2.3 制御 技術

ここでは同期位相制御について制御技術の詳細を紹 介する。

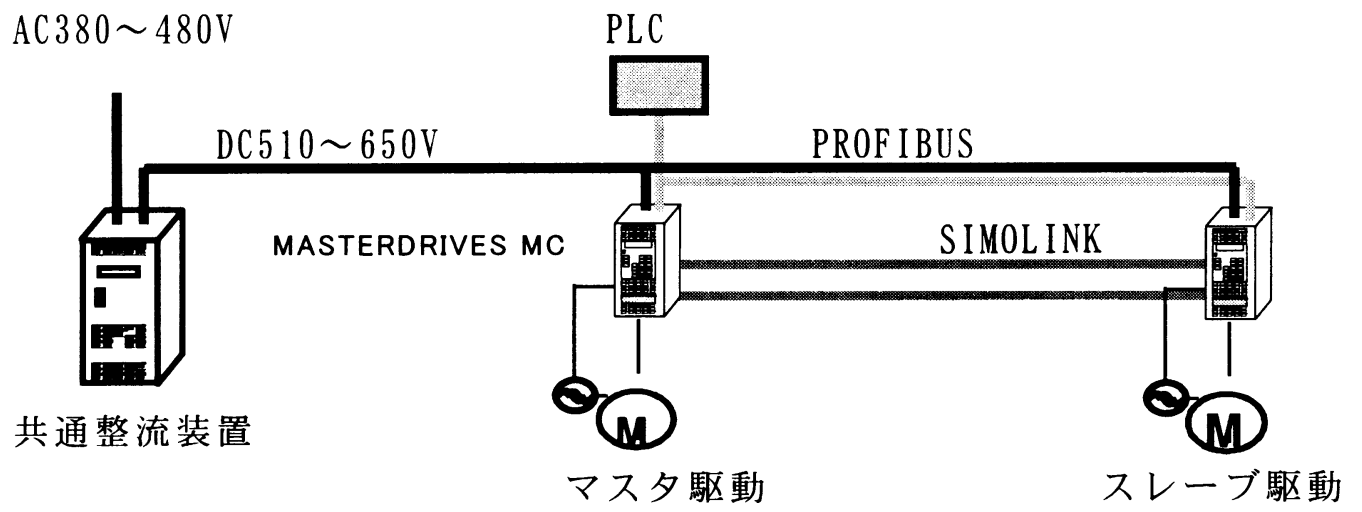

図 1 システム構成例 
1）同期位相制御の要素技術

同期位相制御では，個別の駆動モー夕間で高精度な 同期制御を行うことが重要でそのためには，次のよう な要素技術が確立されていることが必要である。

・ドライブユニット：高速同期制御機能を持ち, 制 御が完全に同期すること。

・通信：高速ドライブ間通信ができること。

・モー夕：低慣性高応答モータであること。

・速度センサ：高分解能エンコーダを有すること。
2）システム構成

同期位相制御の要素技術を満足するシステム構成を 図 1 に示す。

各構成要素の特長は以下の通りである。

・ドライブユニット：MASTERDRIVES MC（Motion Control)

MASTERDRIVES MCは，整流装置内蔵または， 整流装置/回生機能付整流装置と接続するインバータ で，小容量 $(0.5 \mathrm{~kW})$ から大容量 $(200 \mathrm{~kW})$ まで幅 広いレンジで対応している。また，角度同期制御，位

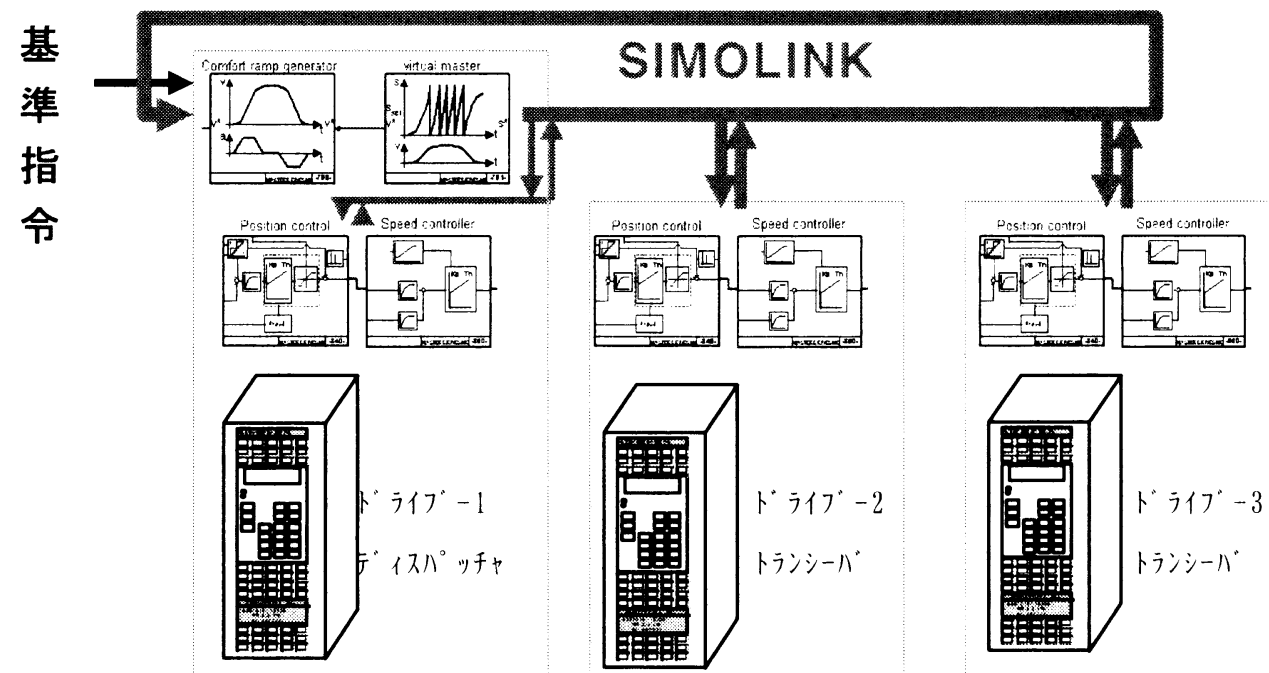

図 2 バーチャルマス夕例

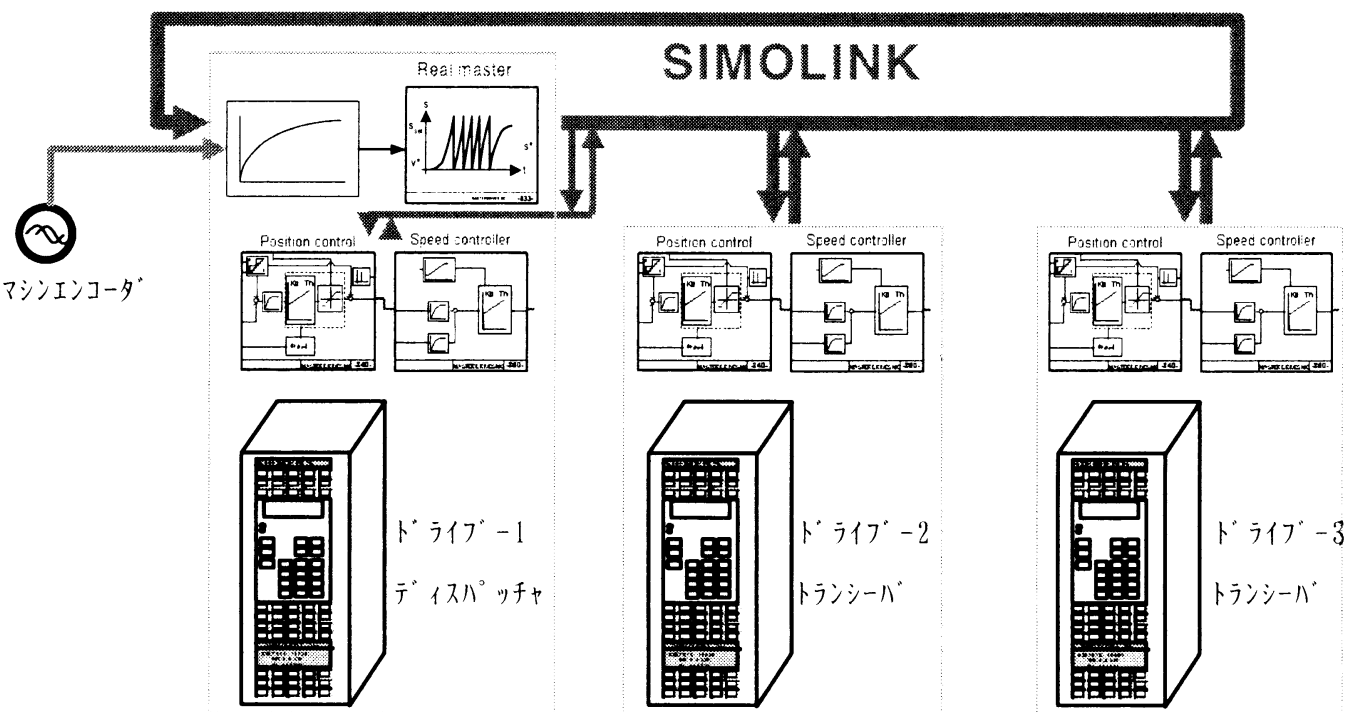

図 3 リアルマス夕例 
置決め, 電子ギヤ, 高精度なリアルマス夕軸などの機 能を備えており，高応答のダイナミック制御性能によ り，角度同期制御時の要求精度を満たすことができる。

MASTERDRIVES MCには, 同期位相制御に必要 な各種機能のソフトウェアが標準装備されており，工 一ザが使用するソフトウェアをパラメータによって設 定することが可能となっている。

・通信：SIMOLINK (Siemens Motion Link)

同期運転ための同期信号と必要な制御信号を伝送す るための通信装置がSIMOLINK で，光信号により超 高速相互通信を実現している。SIMOLINKの機能は 以下の通りである。

（1）ドライブユニット（マスタ）から高速に同期制 御指令設定值を伝送する。

(2) ドライブ間の高速接続。接続された複数のドラ イブの内 1 台がバーチャルマスタ（仮想主軸）又 はリアルマスタ軸を計算し, 他へ送信する。（図

2, 図 3)。

(3) SIMOLINK で接続された全ドライブの計算時 間セク夕を自動認識し同期制御を実行させる。同 期制御に関するSIMOLINKの主な仕様は以下の 通りである。

・11 Mbps の通信速度を有し, 32 ビット 100 データ を $630 \mu \mathrm{s}$ で送・受信可能

・高精度クォーツクロックを使用し, 乱れのない同 期制御を実現

・1 マスタに対して 200 スレーブまでのユニットが

\section{接続可能}

•モータ : MASTERDRIVES MOTOR

独自のフレームレス構造によりコンパクトに設計さ れており，低慣性ロー夕による高応答性を実現してい る。このモータは, 可変速ドライブ用に設計されたも のであり，誘導電動機または同期電動機の 2 種類があ る。

・速度センサ：絶対值エンコーダ

モー夕に内蔵される絶対值エンコーダ（ $\sin / \cos ） は$ 非常に高い分解能を有しており，信号の合成により $16,777,216 / \mathrm{REV}$ の高分解能を実現している。ライン 駆動においては 4096 回転まで絶対值となるマルチ夕 ーン式を採用している。

3. $400 \mathrm{~V}$ 級 3 レベル PWM 制御インバータ

これまで, 電压型 PWM インバータの 3 レベル化 は高压インバー夕において実用化されていたが, 3 レ ベル化することでIGBT 素子が 2 レベル PWM イン バー夕に比べ 2 倍に増えコスト高となる懸念から低圧 汎用インバータでは 3 レベルの実用化はされていなか った。(株安川電機では $400 \mathrm{~V}$ 級インバータでの 3 レベ ル PWM 制御の対環境性能に着目し, 従来の 2 レ心゙ ル PWM インバー夕相当のコストに抑えることで, 世界で初めて $400 \mathrm{~V}$ 級 3 レベル PWM インバータを 開発した。

本章では $400 \mathrm{~V}$ 級 3 レベル PWM インバータ VARI SPEED G 7 ついて紹介する。

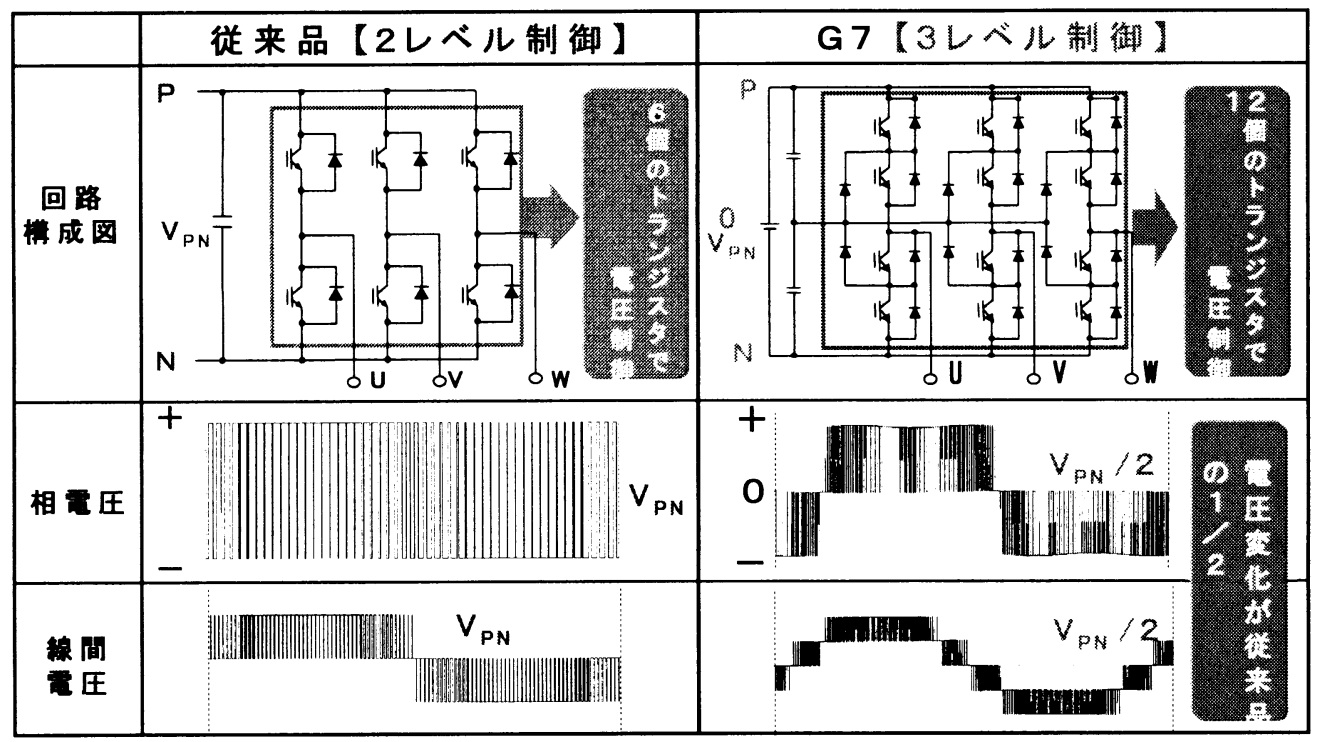

図 4 インバー夕主回路方式比較 


\section{$3.1400 \mathrm{~V}$ 級 3 レベル PWM インバータの特長}

VARISPEED G 7 では, PWM 制御の 3 レベル化に より従来からの $400 \mathrm{~V}$ 級インバー夕制御に抢ける潜在 問題であるサージ電圧によるモー夕絶縁損傷, 軸電圧 によるモー夕軸受電触等の問題を一挙に解決した。更 にサージ抑制フィル夕無しで汎用モー夕や既設モー夕 も安心してインバータドライブできるようになったた め, 設備投資コスト負担が軽減でき, かつ漏れ電流や 発生ノイズも従来比半減相当に大幅に低減した。

また，世界のフィールドネットワークに対応（RS$422 / 485$ は標準装備）しており，フレキシブルなシス テム構築が容易に行えるようになっている。

\subsection{3レベル PWM 制御の原理}

VARISPEED G 7 の $400 \mathrm{~V}$ 級 3 レベル PWM 制御は, インバー夕内の主回路直流電圧をコンデンサにより 2 分割し,さらに出力 1 相当たり 4 個直列に接続した卜 ランジスタによって, +・-Bびゼロの 3 レベルの電 压を出力する事ができる主回路方式である（図 4)。

スイッチングによる出力電圧の変化率が従来の 2 レ ベル PWM 方式インバータの半分になるため, モー 夕や電源に与えていた電気的悪影響を大幅に軽減する 事に成功した。

\section{3 サージ電圧}

2 レベル PWM 制御の場合最大で直流母線電圧の約 2 倍のサージ電圧になるのに対して, 3 レベル PWM 制御ではサージ電圧は最大でも 1.5 倍に抑制される (図 5)。これらの検証を, 使用電線や絶縁方法などの 異なる世界各国のモー夕を用い, 商用電源ではなく実 際のインバータサージ電圧を印加し, 部分放電（コロ
ナ放電）の有無を確認する方法で行った。

この結果, 例えば相間絶縁では, 最も放電電圧が低 かったモー夕 $(1,250 \mathrm{~V})$ に対しても, 3 レベル PWM のサージ電压は $976 \mathrm{~V}$ （電源電圧 $460 \mathrm{~V}$ 時）と充分に 低く, また同様に線間絶縁, 対地絶縁に対しても通常 の使用状態では殆ど問題にならないサージレベルまで 低減されている事が判明した（古いモータで元々モー 夕の絶縁が低下している場合や, 汎用モー夕に低速で 高トルクを印加したような場合の過熱保護については 別途検討が必要)。

3 レベル PWM 制御ではサージ電圧が $400 \mathrm{~V}$ 級モー 夕の耐圧以下となるため, 絶縁劣化に影響を及ぼさな い。つまりサージ電圧対策無しで, 沉用モー夕が使用 可能となる。

\section{4 軸 電 流}

モー夕軸受けの軸電流值は中性点電圧にほぼ比例し ている。3 レベル PWM 方式では, 中性点電圧が原理 的に 2 レベル PWM の約 2/3 (400 Vp-p）であり, 軸 電流も減少している。図6に当社 VARISPEED-616 G 5 インバータ（2レベル）と比較したグラフを示す。

\section{5 その他の特長・メリット \\ 1) ノイズについて}

出力電圧の変化率が 2 レベル PWM 方式の $1 / 2$ の 為, 放射ノイズ (雑音電界強度) で約 $20 \mathrm{~dB}$, 伝導, イズが約 $5 \mathrm{~dB}$ 低隇している。このため, ノイズフィ ルタの除去又は小型化が可能となっている。

2) 漏れ電流について

モータやケーブルの対地静電容量と, インバータ出 力電圧の変化率による高調波漏れ電流も, ピーク值で

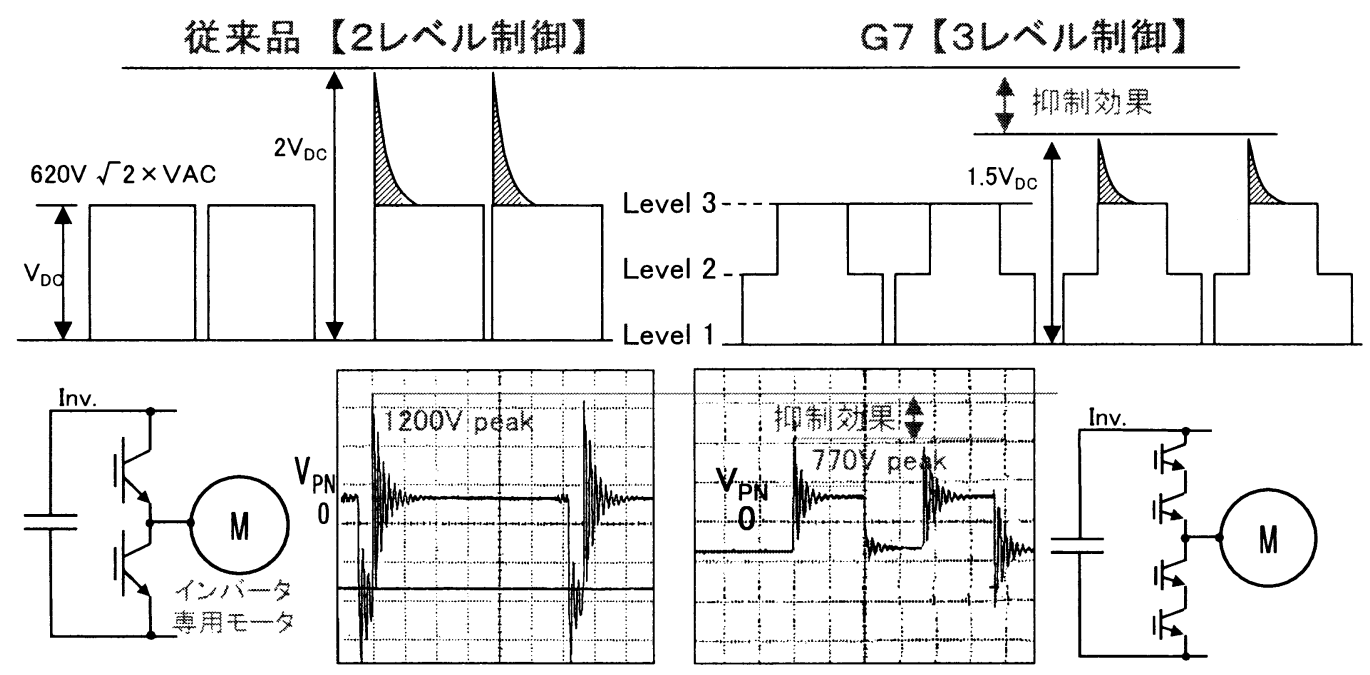

図 $5440 \mathrm{~V}$ 電源でのサージ電圧比較 


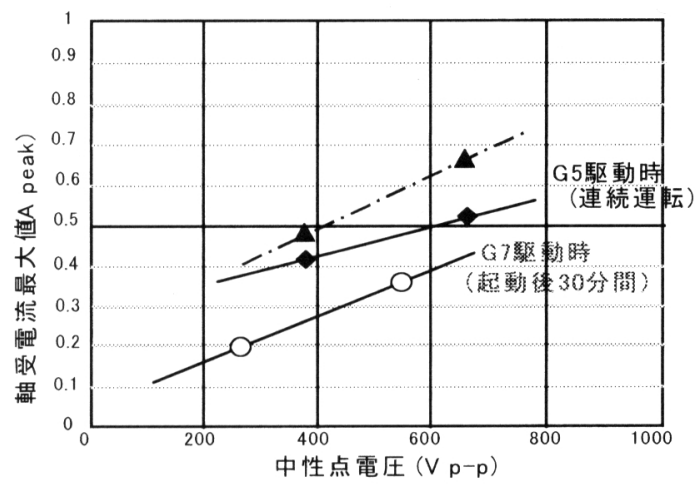

中性点電圧に対する軸受電流 (中性点電圧を試験的に変動させて測定)

図 6 軸電流比較

2 レベル PWM 方式の約半分に低減している。

3）音について

同一のキャリア周波数に扔いても電流・電压の高調 波成分が低く, モ一夕内部高調波電磁力の影響が軽減 され低騷音になる。3 レベル PWM で $8 \mathrm{kHz}$ のキャリ ア周波数は, 2 レベル PWM の $16 \mathrm{kHz}$ 相当になり，低 キャリアでありながら低騒音を実現している。

4) チューニング機能について

従来の回転型オートチューニングに停止型オートチ ユーニング, 線間抵抗のみの停止型オートチューニン グの 2 種類が追加されている。

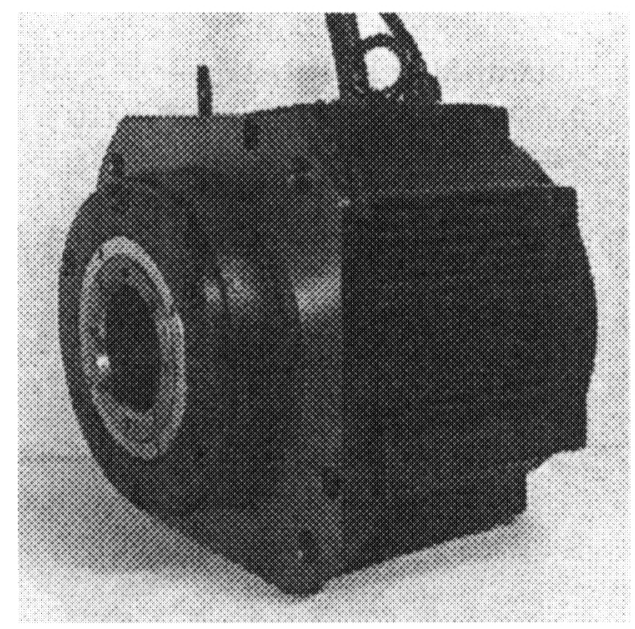

図 7 中空シャフト AC サーボドライブ

\section{4. 新しいドライブ製品の紹介}

4.1 中空シャフト AC サーボドライブ

(Hollow shaft AC servo drive)

従来のモータシャフトが中空形状になっているため 機械シャフトやボールねじなどに直接取り付けが可能 となり，スペースの削減効果が大である（図 7)。

製紙機械への応用例として, スリッ夕昒位置決め 駆動, スリッタ用ワインダ駆動などが挙げられる。200 $\mathrm{V}$ 級で 1.1/1.5/2.2/3.2/4.0 kW をラインアップして いる(表 1)。

表 1 中空シャフト ACサーボ仕様

\begin{tabular}{|c|c|c|c|c|c|c|}
\hline \multicolumn{2}{|c|}{ サーボモー夕型式 } & \multirow{2}{*}{\begin{tabular}{|c|} 
SGMT-11 A $3 \mathrm{~V}$ \\
1.1 \\
\end{tabular}} & \multirow{2}{*}{\begin{tabular}{|c|} 
SGMT-15 A 2 A \\
1.5
\end{tabular}} & \multirow{2}{*}{\begin{tabular}{|c|} 
SGMT-22 A 2 A \\
2.2 \\
\end{tabular}} & \multirow{2}{*}{\begin{tabular}{|c|} 
SGMT-32 A 2 A \\
3.2
\end{tabular}} & \multirow{2}{*}{$\begin{array}{c}\text { SGMT-40 A } 2 \mathrm{~A} \\
4.0 \\
\end{array}$} \\
\hline 定格出力 & $\mathrm{kW}$ & & & & & \\
\hline 定格トルク & $\mathrm{N} \cdot \mathrm{m}(\mathrm{kgf} \cdot \mathrm{cm})$ & $7.16(73)$ & $7.16(73)$ & $10.5(107)$ & $15.3(156)$ & $19.1(195)$ \\
\hline 瞬時ピークトル， & $\mathrm{N} \cdot \mathrm{m}(\mathrm{kgf} \cdot \mathrm{cm})$ & $20.6(210)$ & $18.2(186)$ & $38.8(396)$ & $66.9(682)$ & $78.5(800)$ \\
\hline 定格電流 & Arms & 10.7 & 11.8 & 16.0 & 20.0 & 21.7 \\
\hline 瞬時最大電流 & Arms & 28 & 28 & 56 & 84 & 84 \\
\hline 定格回転数 & $\min ^{-1}$ & 1,500 & 2,000 & 2,000 & 2,000 & 2,000 \\
\hline 最大回転数 & $\min ^{-1}$ & 3,000 & 2,500 & 2,500 & 2,500 & 2,500 \\
\hline 適用エンコーダ & & $\begin{array}{c}\text { インクリメンエンコーダ } \\
2048 \mathrm{P} / \mathrm{R}\end{array}$ & \multicolumn{4}{|c|}{ インクリメントエンコーダ $8192 \mathrm{P} / \mathrm{R}$} \\
\hline イナーシャ & $\operatorname{kgm}^{2}\left(\mathrm{gf} \cdot \mathrm{cm} \cdot \mathrm{s}^{2}\right)$ & $44.4 \times 10^{-4}(45.3)$ & $130 \times 10^{-4}(132)$ & $148 \times 10^{-4}(151)$ & $163 \times 10^{-4}(166)$ & $223 \times 10^{-4}(227)$ \\
\hline 適用サーボドライ & イバ型式 & SGDB-15 ADT & SGDB-15 ADT & SGDB-30 ADT & SGDB-44 ADT & SGDB-44 ADT \\
\hline
\end{tabular}




\section{2 インバータ搭載モータドライブ}

(SIMODRIVE POSMO A)

本ドライブはオンボードのループ制御とパワーモジ ユールを搭載したインテリジェント分散制御型サーボ モータで, 位置決め機能を内蔵L, PROFIBUS-DP ネットワークにも標準スレーブとして接続可能である。

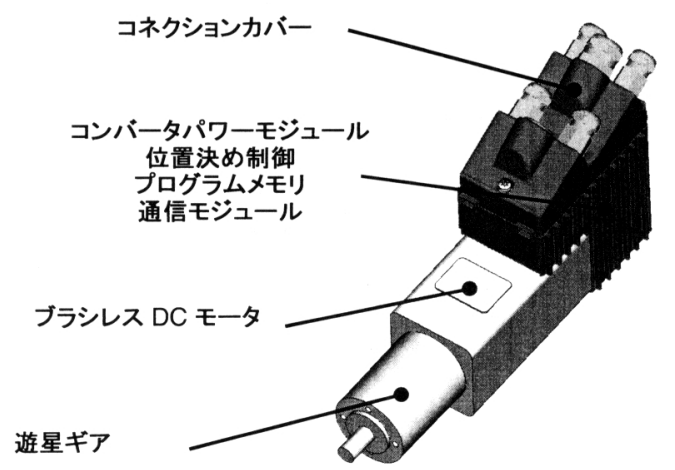

図 8 SIMODRIVE POSMO A 本体外形図

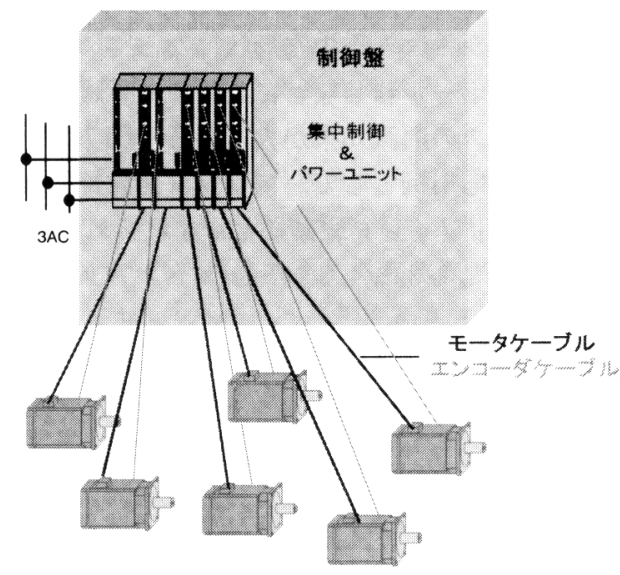

従来のインバータドライブ
通信バスとパワーバスを搭載しているため, 複数駆動 する場合の省配線と制御盤レス化が実現できる（図８， 図 9)。容量的には $75 \mathrm{~W}$ と $300 \mathrm{~W}$ をラインアップし ている（表 2）。製紙機械への応用例として，コータ 薬液装置駆動などが挙げられる。

5.おわりに

以上「新しいドライブ技術の考察」というテーマの もと，当社の取り組んでいる事例について紹介した。 これらの製品を展開していく上での御意見を㧍聞かせ いただければ幸いである。

製紙業界では今後省エネはもち万んのこと, 設備の 高速化，ネットワーク化が進み，環境問題に対する要 求も益々強くなってくる。当社としても，これらの動 向を充分に把握し, 今後も研鑚を重䄈ていく所存であ る。

\section{参考資料・文献}

1）シャフトレス印刷の特徴と応用，侏加工技術研究 会刊「コンバーテック」2000 年 11 月号

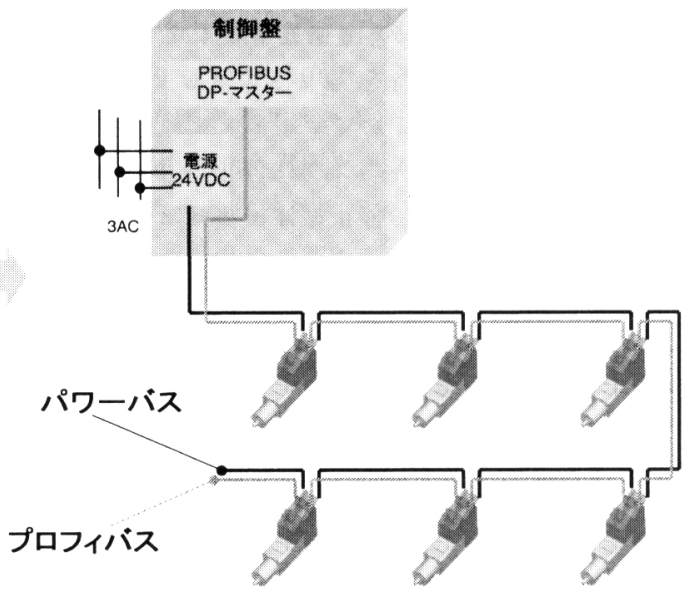

インバータ搭載モータドライブ

図 9 SIMODRIVE POSMO A による省配線化と制御盤レス化

表 2 インバータ搭載モータドライブ（SIMODRIVE POSMO A）仕様

\begin{tabular}{l|c|c}
\hline & $75 \mathrm{~W}$ & $300 \mathrm{~W}$ \\
\hline $\begin{array}{l}\text { 定格電压 } \\
\text { 定格回転数 }\end{array}$ & $24 \mathrm{VDC}$ & $48 \mathrm{VDC}$ \\
定格トルク & $3,300 \mathrm{~min}^{-1}$ & $3,000 \mathrm{~min}^{-1}$ \\
位置検出システム & $0.36 \mathrm{Nm}$ & $0.95 \mathrm{Nm}$ \\
保護等級 & インクリメンタル $816 \mathrm{P} / \mathrm{R}$ & インクリメンタル $4096 \mathrm{P} / \mathrm{R}$ \\
重量 & $\mathrm{IP} 54$ & $\mathrm{IP} 54$ \\
周囲温度 & $3.7 \mathrm{~kg}$ & $4 \sim 5.5 \mathrm{~kg}$ \\
\hline
\end{tabular}

